\title{
Temperature-Dependence of Protein Solution Viscosity and Protein-Protein Interactions: Insights Into the Origins of High-Viscosity Protein Solutions
}

Mahlet A. Woldeyes ${ }^{1}$, Wei Qi $^{2}$, Vladimir I. Razinkov ${ }^{2}$, Eric M. Furst ${ }^{1 *}$, Christopher J. Roberts ${ }^{1 *}$

${ }^{I}$ Department of Chemical \& Biomolecular Engineering, University of Delaware, Newark, Delaware 19716, United States

${ }^{2}$ Drug Product Development, Amgen Inc., Thousand Oaks, California 91320, United States

\section{Supporting Information}
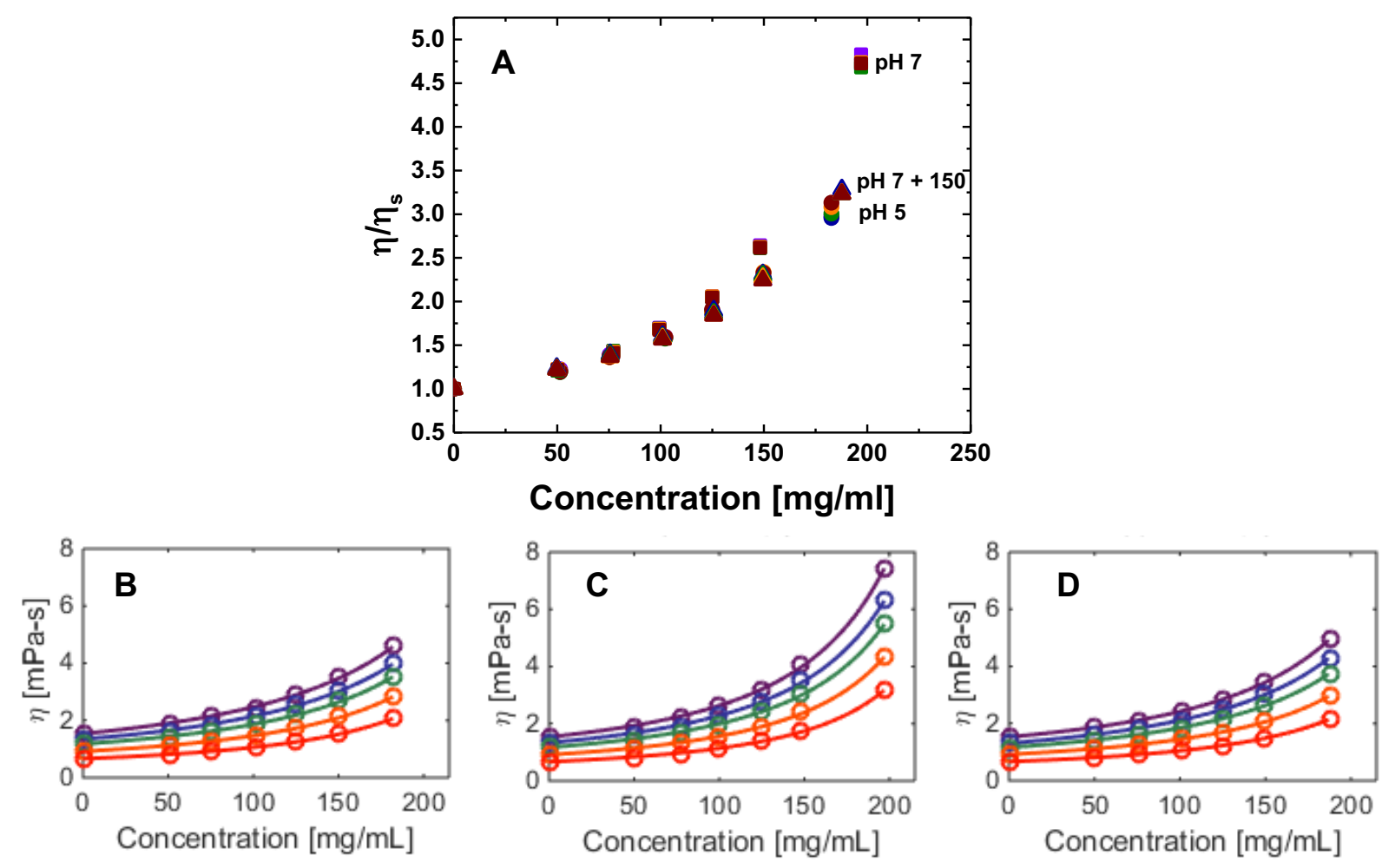

Figure S1. (A) Relative viscosity as a function of protein concentration for aCgn at $\mathrm{pH} 7$ (squares), $\mathrm{pH} 7$ with $\mathrm{NaCl}$ (triangles), and $\mathrm{pH} 5$ (circles). Bottom panel: solution viscosity as a function of concentration at (B) $\mathrm{pH} 5$ (C) $\mathrm{pH} 7$ (D) $\mathrm{pH} 7+150 \mathrm{mM} \mathrm{NaCl}$. The different colors correspond to different temperature and lines are fits to Ross-Minton Model (equation 3). 

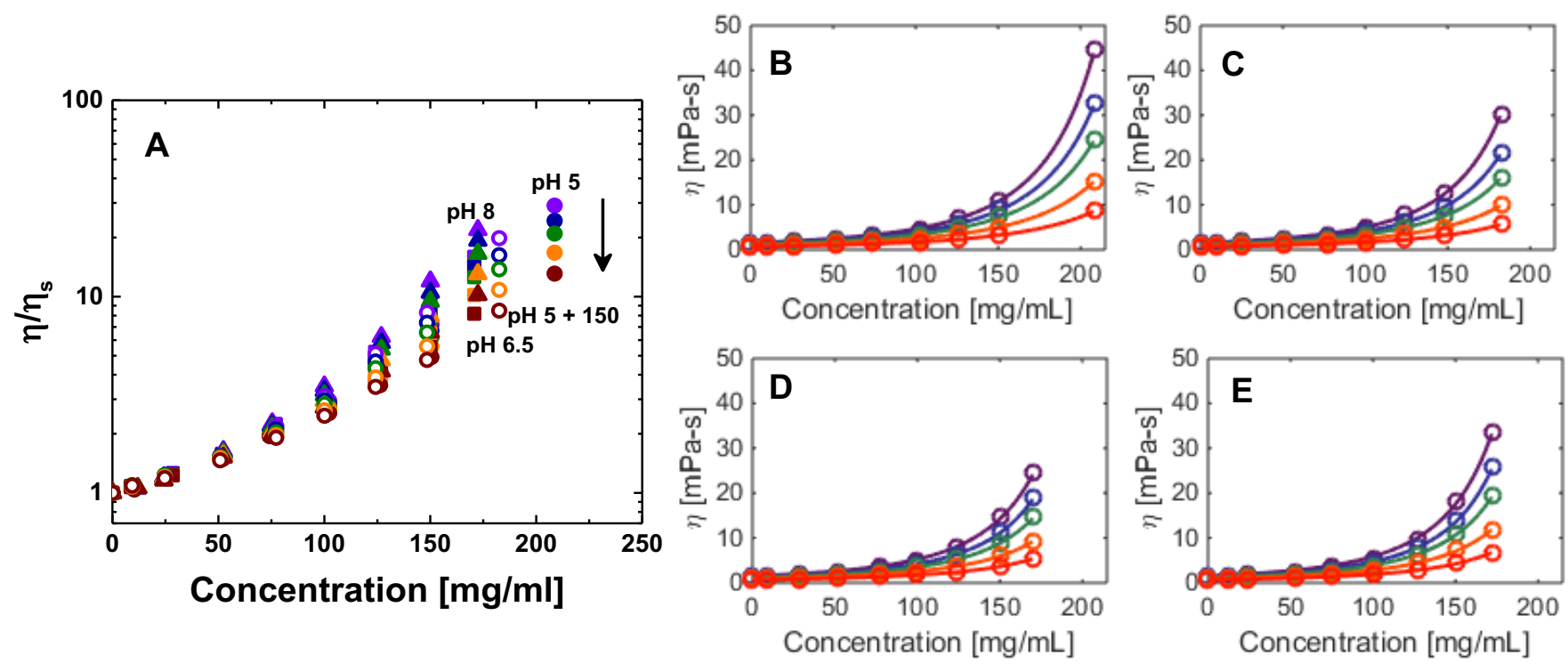

Figure S2. (A) Relative viscosity as a function of protein concentration for MAb1 at $\mathrm{pH} 5$ (closed circles), $\mathrm{pH} 6.5$ (squares), $\mathrm{pH} 8$ (triangles), and $\mathrm{pH} 5$ with $\mathrm{NaCl}$ (open circles). The arrow indicates increasing temperature. (B-E) Solution viscosity for MAb1 as a function of concentration at (B) $\mathrm{pH} 5$ (C) $\mathrm{pH} 5+150 \mathrm{mM} \mathrm{NaCl}$ (D) pH 6.5 (E) pH 8. The different colors correspond to different temperature. and lines are fits to Ross-Minton Model (equation 3).

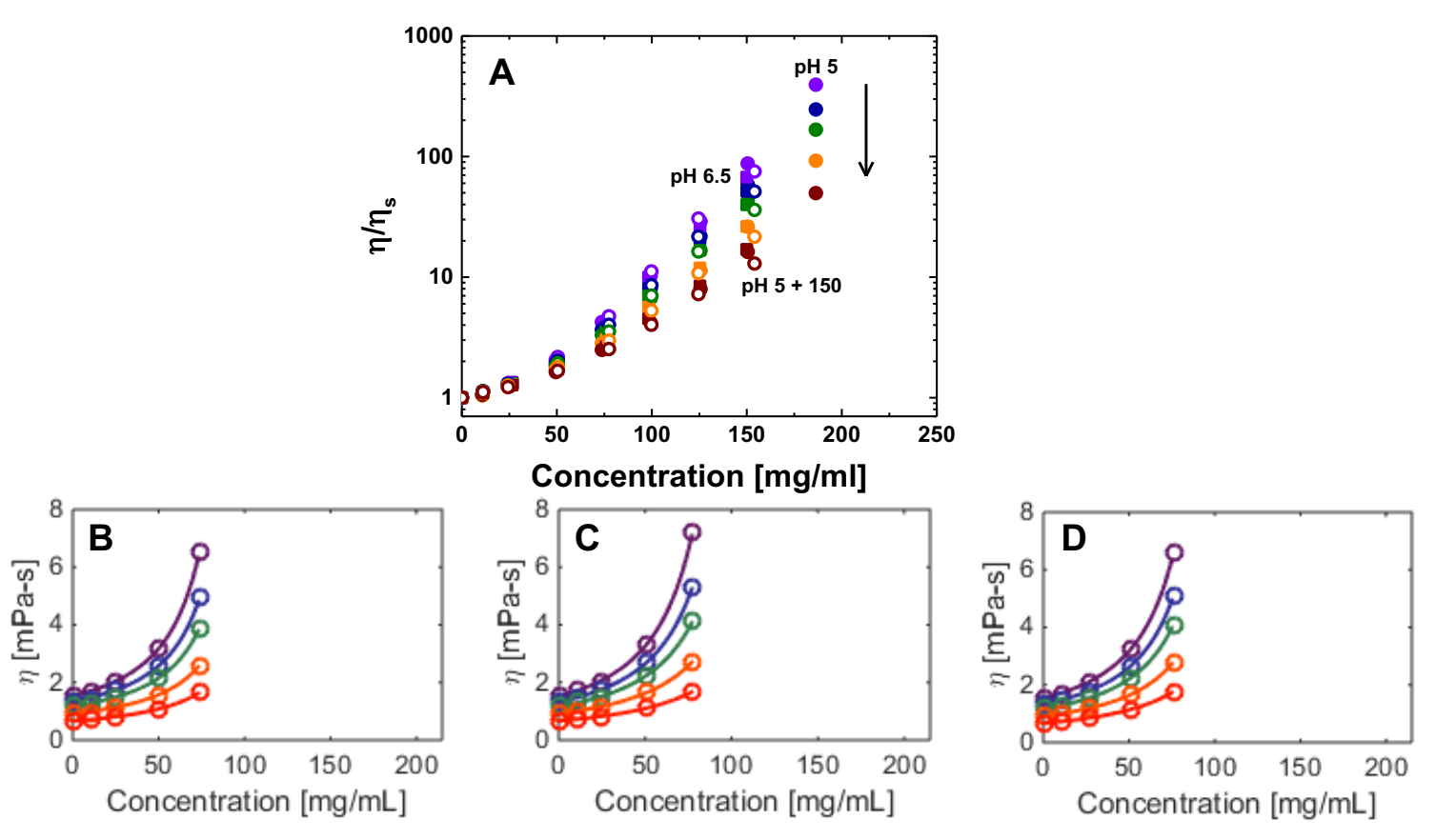

Figure S3. Relative viscosity as a function of protein concentration for MAb4 at $\mathrm{pH} 5$ (closed circles), $\mathrm{pH} 6.5$ (squares), and $\mathrm{pH} 5$ with $\mathrm{NaCl}$ (open circles). The arrow indicates increasing temperature. (B-D) Solution viscosity as a function of concentration at (B) $\mathrm{pH} 5$ (C) $\mathrm{pH} 5+150$ $\mathrm{mM} \mathrm{NaCl}$ (D) $\mathrm{pH}$ 6.5. The different colors correspond to different temperature and lines are fits to Ross-Minton Model (equation 3). As discussed in the manuscript, for MAb4 a significant 
deviation from the model was observed when including all $\mathrm{c}_{2}$, therefore the fit was done for concentrations up to $75 \mathrm{mg} / \mathrm{mL}$.
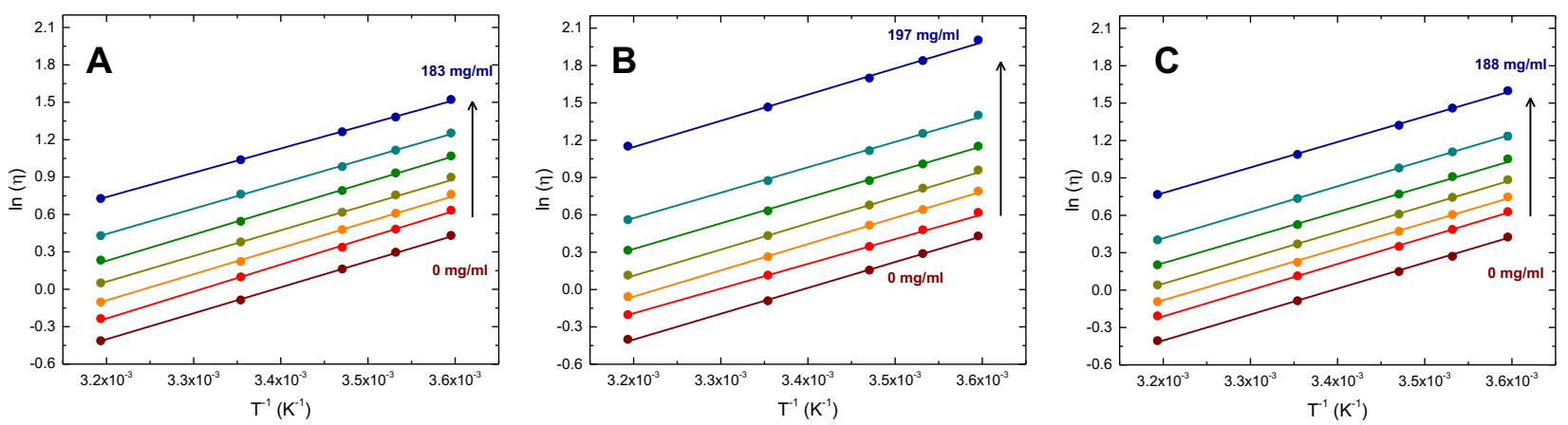

Figure S4. $\ln (\eta)$ as a function of $1 / T$ for aCgn at (A) $\mathrm{pH} 5$ (B) $\mathrm{pH} 7$ (C) $\mathrm{pH} 7+150 \mathrm{mM} \mathrm{NaCl}$. The arrows indicate increasing protein concentration and the lines correspond to fits to AndradeEyring model (equation 4).
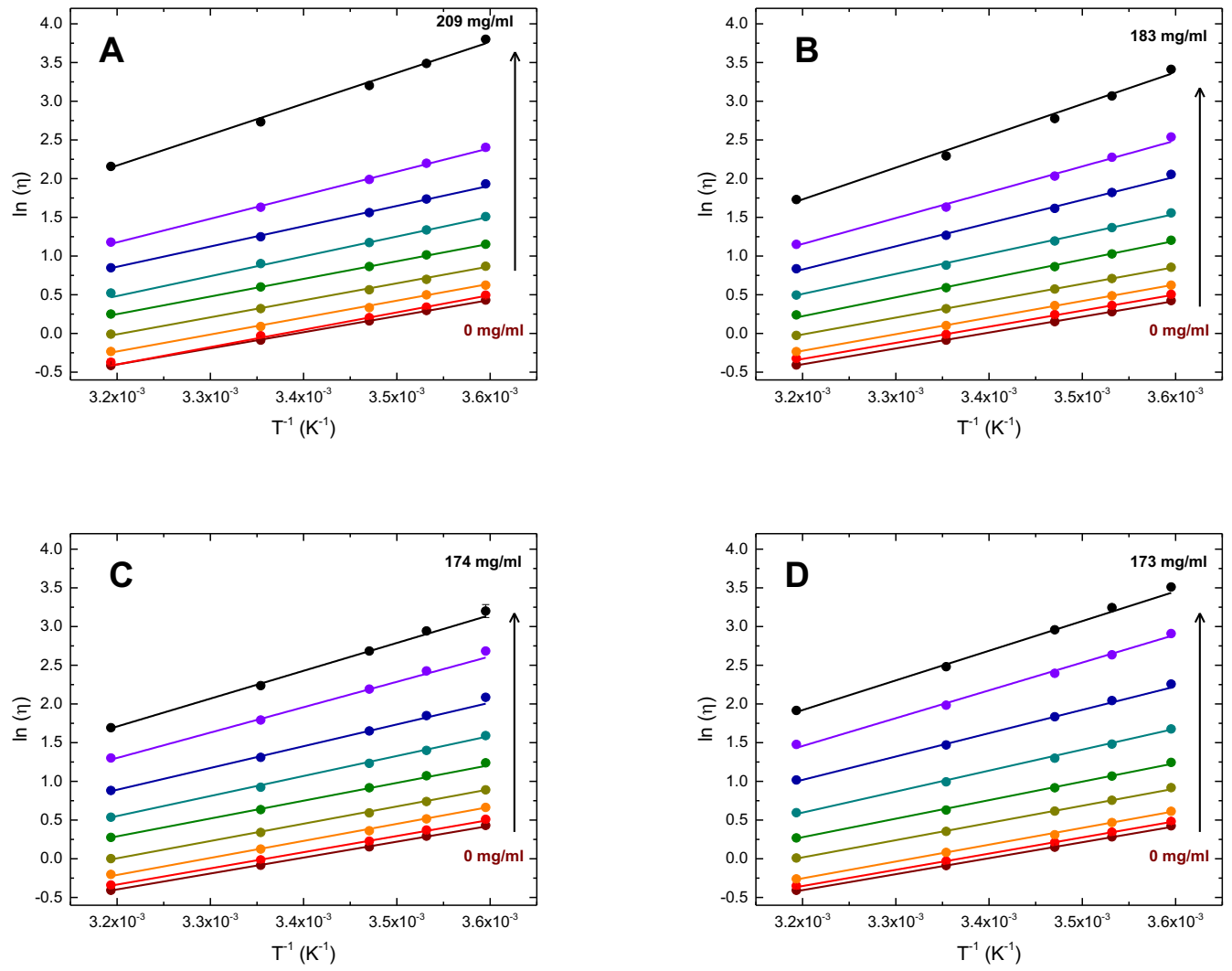

Figure S5. $\ln (\eta)$ as a function of $1 / T$ for $\mathrm{MAb} 1$ at (A) $\mathrm{pH} 5(\mathrm{~B}) \mathrm{pH} 5+150 \mathrm{mM} \mathrm{NaCl}(\mathrm{C}) \mathrm{pH} 6.5$ (D) $\mathrm{pH}$ 8. The arrows indicate increasing protein concentration and the lines correspond to fits to Andrade-Eyring model (equation 4). 

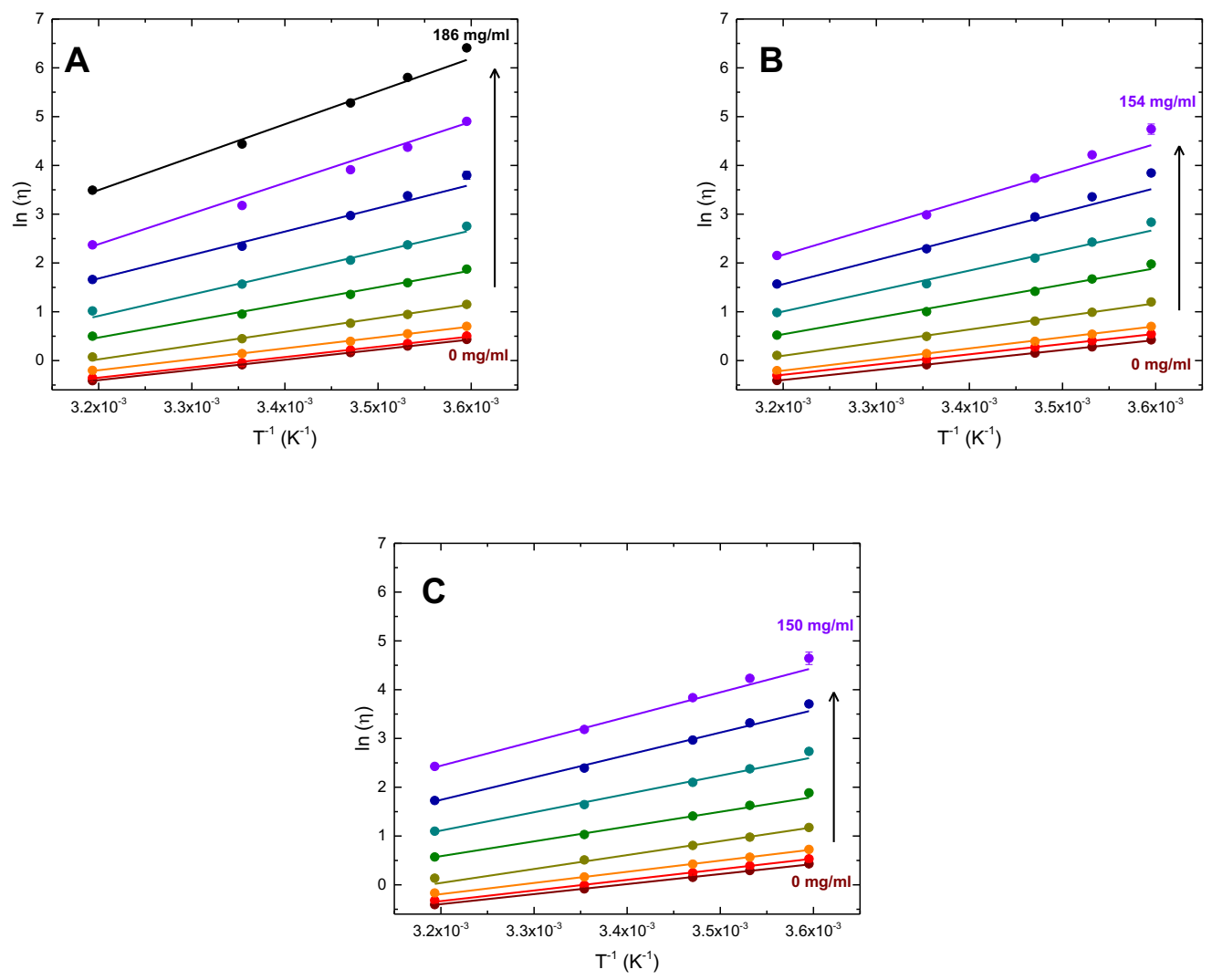

Figure S6. $\ln (\eta)$ as a function of $1 / T$ for MAb4 at (A) $\mathrm{pH} 5(\mathrm{~B}) \mathrm{pH} 5+150 \mathrm{mM} \mathrm{NaCl}(\mathrm{C}) \mathrm{pH}$ 6.5. The arrows indicate increasing protein concentration and the lines correspond to fits to Andrade-Eyring model (equation 4).

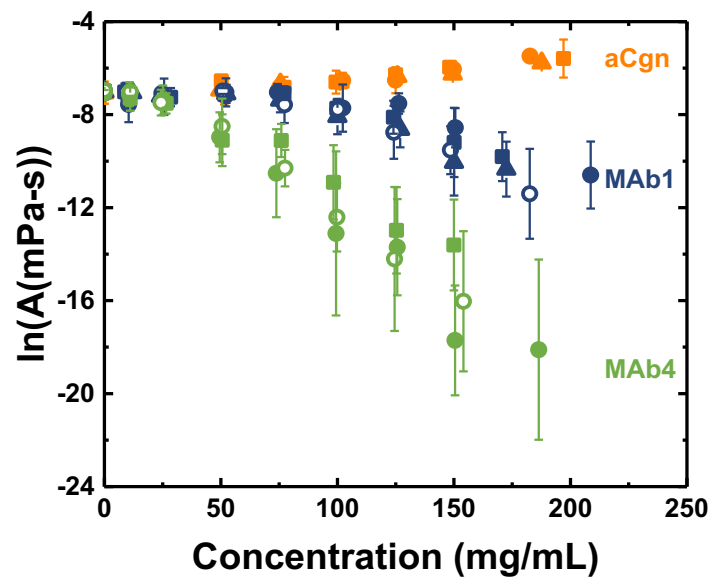

Figure S7. The pre-exponential factor $(\ln (A))$ as a function of protein concentration for aCgn (orange symbols), MAb1 (blue symbols), and MAb4 (green symbols) in various formulation 
conditions. The formulation conditions are: for aCgn at $\mathrm{pH} 7$ (squares), $\mathrm{pH} 7$ with $\mathrm{NaCl}$ (triangles), and $\mathrm{pH} 5$ (circles); and for the MAbs at pH 5 (closed circles), $\mathrm{pH} 6.5$ (squares), $\mathrm{pH} 8$ (triangles), and $\mathrm{pH} 5$ with $\mathrm{NaCl}$ (open circles).
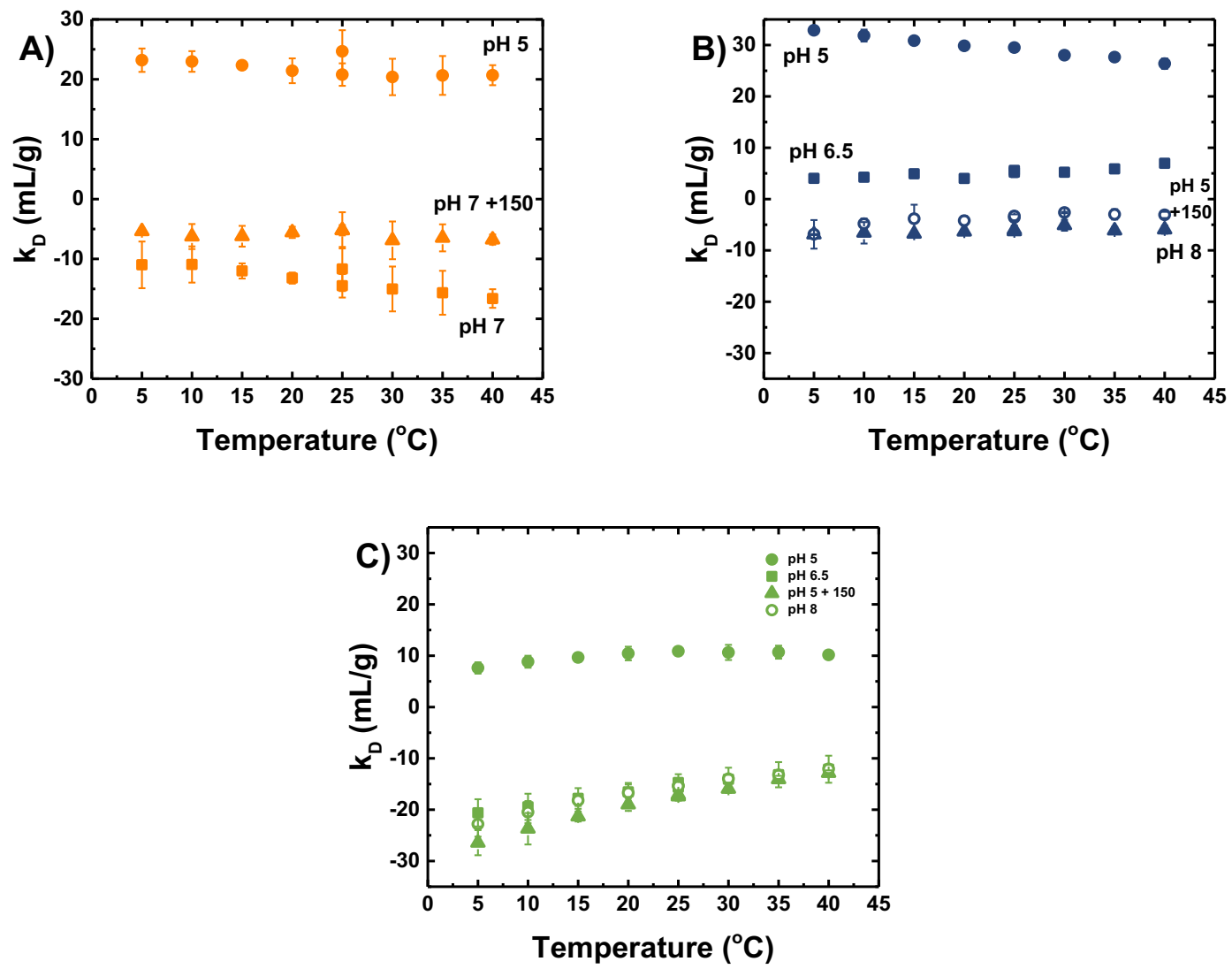

Figure S8. Protein interaction parameter $\left(k_{D}\right)$ as a function of temperature for: (A) aCgn at $\mathrm{pH} 7$ (squares), $\mathrm{pH} 7$ with $\mathrm{NaCl}$ (triangles), and $\mathrm{pH} 5$ (circles); (B) MAb1 at $\mathrm{pH} 5$ (closed circles), $\mathrm{pH}$ 6.5 (squares), $\mathrm{pH} 8$ (triangles), and $\mathrm{pH} 5$ with $\mathrm{NaCl}$ (open circles); (C) MAb4 at $\mathrm{pH} 5$ (closed circles), $\mathrm{pH} 6.5$ (squares), $\mathrm{pH} 8$ (triangles), and $\mathrm{pH} 5$ with $\mathrm{NaCl}$ (open circles). The error bars correspond to $95 \%$ confidence intervals of the fit parameters. 